Turkish Online Journal of Qualitative Inquiry (TOJQI)

Volume 10, Issue 3, July 2019: 321-345

DOI: $10.17569 /$ tojqi. 515616

Research Article

\title{
Integrating Multiple Intelligences into Daily Plans: A Preschool Example
}

\author{
Tanju Gürkan ${ }^{1}$, Çağlayan Dinçer ${ }^{2}$, Burcu Çabuk ${ }^{3}$
}

\begin{abstract}
The purpose of this qualitative study was to evaluate the effectiveness of Multiple Intelligences Theory (MI) on preschool children's learning styles, interests and active participation to the daily activities. Researchers conducted a two-phased study in an urban preschool classroom of 14 children who are at the age of 6 with the cooperation of the classroom teacher. In the first phase, the teacher made observations of her class to decide the dominant intelligences, learning styles, interests and participation of the children while she was conducting her traditional semi-structured daily plans based on the National Preschool Education Curriculum. Based on the observations, for each child, she filled out the MI Inventory (MULIN) developed by the researchers. Then, each child was interviewed by one of the researchers and asked to mark the MI Self Evaluation Picture Control List (MISEC) developed by Fleetham (2008). The data collected was graphed and interpreted to conclude the MI Profile of the class. In the second phase, children were exposed to the Daily Plan Enriched with MI Inspirations in the leadership of the teacher. Researchers observed and videotaped the whole procedure. Then, the teacher was interviewed to find out whether there were differences on the children's interests and active participation during the daily plan enriched with MI inspirations comparing with the traditional daily plans she has been conducting. The findings of the study showed that Daily Plan Enriched with MI Inspirations made a positive effect on children's interests and active participation in the daily activities since they covered all the intelligences and addressed different learning styles of the children. Research findings not only provide insight into the role of MI on preschool children's interests and active participation but also draw attention to the importance of having all the eight intelligence and addressing all the learning styles of the children in the daily plans.
\end{abstract}

Keywords: Multiple Intelligences, daily plan, preschool education, interest, active participation, learning style

\footnotetext{
1 Retired Prof.Dr., Ankara University, Faculty of Educational Sciences, Department of Curriculum and Instruction, tnjgurkan@gmail.com, https://orcid.org/0000-0002-6122-2200.

2 Prof.Dr., Hasan Kalyoncu University, Faculty of Education, Department of Preschool Education, fcdincer@gmail.com, https://orcid.org/0000-0001-5468-9155.

3 Res.Ass.Dr., Ankara University, Faculty of Educational Sciences, Department of Preschool Education, cabuk@education.ankara.edu.tr, https://orcid.org/0000-0003-1166-9773.
}

Received: 21.01.2019, Accepted: 30.07.2019 


\title{
Çoklu Zeka Kuramı’nı Günlük Planlara Entegre Etme: Bir Anaokulu Örneği
}

\begin{abstract}
$\ddot{\mathbf{O z}}$
Bu nitel araştırmanın amacı, Çoklu Zeka Kuramı'nın okul öncesi dönem çocuklarının öğrenme stilleri, ilgi alanları ve günlük aktivitelere aktif katılımları üzerindeki etkililiğini değerlendirmek olarak belirlenmiştir. Araştırmacılar, sınıfın öğretmeninin işbirliği ile 6 yaşındaki 14 çocuğun şehir içinde yer alan anaokulu sınıfında iki aşamalı bir çalışma yürütmüşlerdir. Birinci aşamada öğretmen, Okul Öncesi Eğitim Programı'na dayanan yarı yapılandırılmış geleneksel günlük planlarını yürütürken, çocukların baskın zekalarına, öğrenme stillerine, ilgi alanlarına ve aktif katılım durumlarına karar vermek amacıyla sınıf gözlemleri yapmıştır. Gözlemlerine dayanarak, her çocuk için, araştırmacılar tarafından geliştirilen Çoklu Zeka Envanteri'ni (MULIN) doldurmuştur. Daha sonra araştırmacılardan biri her çocukla görüşmeler yapmış ve Fleetham (2008) tarafından geliştirilen Çoklu Zeka Öz Değerlendirme Resim Kontrol Listesi'ni (MISEC) işaretlemelerini istemiştir. Toplanan veriler sınıfın Çoklu Zeka Profili'ni oluşturmak amacıyla grafikler haline dönüştürülüp yorumlanmıştır. İkinci aşamada, çocuklara, öğretmen liderliğinde, Çoklu Zeka Kuramı'ndan Esinlenilerek Zenginleştirilen Günlük Plan uygulanmıştır. Araştırmacılar sürecin tüm aşamalarını gözlemleyerek videoya kaydetmişlerdir. Daha sonra öğretmenin, Çoklu Zeka Kuramı'ndan esinlenilerek zenginleştirilen günlük planı, geleneksel günlük planlarıyla karşılaştırdığında çocukların ilgileri ve aktif katılımları konusunda farklılıklar olup olmadığ1 yönündeki görüşlerini öğrenmek amacıyla görüşmelere katılmıştır. Çalışmanın bulguları, Çoklu Zeka Kuramı'ndan Esinlenilerek Zenginleştirilen Günlük Plan'ın, tüm zeka türlerini kapsadığı ve çocukların farklı öğrenme stillerini ele aldığı için çocukların ilgi alanlarına ve günlük aktivitelere aktif katılımına olumlu yönde etki ettiğini göstermiştir. Araştırmanın sonuçları, Çoklu Zeka'nın okul öncesi dönem çocuklarının ilgileri ve aktif katılımları üzerindeki rolü hakkında fikir vermenin yanı sıra, sekiz zeka türünün tümünü kapsamanın ve günlük planlarda çocukların tüm öğrenme stillerini ele almanın önemine dikkat çekmektedir.
\end{abstract}

Anahtar Kelimeler: Çoklu zeka, günlük plan, anaokulu eğitimi, ilgi, aktif katılım, öğrenme stili 


\section{Introduction}

Preschool teachers' main purpose of preparing daily plans is mainly for the children to learn the essentials through fun, engaging and meaningful activities ranging from art activities to short trips. In a typical preschool classroom, teachers have a duty to not forget the importance of a colorful and stimulating atmosphere. Preschoolers constantly need to be surrounded by hands-on activities, as well as visual reinforcements. An ideal daily plan needs to be divided into sections, namely interactive big and small group and individual work. In this thoughtprovoking context, the children are able to accomplish goals presented by an attentive daily plan. After Gardner (1983) introduced the Theory of Multiple Intelligences to the area of education, by the practitioners, there is a raising trend of preparing curriculum by the inspiration of this theory.

Howard Gardner's (1983) view of intelligence is rapidly being incorporated in the daily plans in schools worldwide. In his theory of Multiple Intelligences, Gardner expanded the concept of intelligence to include different areas such as music and interpersonal knowledge, besides the mathematical and linguistic abilities. People draw on these intelligences, individually and/or corporately to create products and solve problems as they develop (Gardner, 1983, 1993, 1999, 2006a, 2006b) since intelligence is defined as "the capacity to solve problems or to fashion products that are valued in one or more cultural settings" (Gardner \& Hatch, 1989). According to this definition, the eight different intelligences explained by Gardner (2006a) are as follows:

Logical-Mathematical Intelligence consists of the capacity to analyze problems logically, carry out mathematical operations, and investigate issues scientifically. According to Gardner (1983), it "entails the ability to detect patterns, reason deductively and think logically". This intelligence is most often associated with scientific thinking (Bednar, 2002). Linguistic Intelligence involves sensitivity to spoken and written language, the ability to learn languages, and the capacity to use language to accomplish certain goals. This intelligence includes the ability of using the language to express oneself rhetorically or poetically and language as a means to remember the information (Bordelon \& Banbury, 2005). Spatial Intelligence involves the potential to recognize and use the patterns of wide space and more confined areas 
(Highland, 1999). Musical Intelligence involves skills in the performance, composition, and appreciation of musical patterns. It encompasses the capacity to recognize and compose musical pitches, tones, and rhythms. According to Aronoff (1988), Gardner (1983) believes that musical intelligence runs in an almost structural parallel to linguistic intelligence. BodilyKinesthetic Intelligence entails the potential of using one's whole or parts of the body to solve problems. It is the ability to use mental abilities to coordinate physical movements. According to Guss (2005), Gardner sees mental and physical activity as related. Interpersonal Intelligence is concerned with the capacity to understand the intentions, motivations and desires of other people. It allows people to work effectively with others (Rettig, 2005). Intrapersonal Intelligence entails the capacity to understand oneself, to appreciate one's feelings, fears and motivations. According to Gardner, it involves having an effective working model of ourselves and to be able to use such information to regulate our lives (Furnham \& Thomas, 2004). Finally, Naturalistic-Environmental Intelligence enables human beings to recognize, categorize and draw upon certain features of the environment. It "combines a description of the core ability with a characterization of the role that many cultures value" (Carlisle, 2001).

Thousands of schools across the world have incorporated Multiple Intelligences principles into their curriculum, and in numerous languages, hundreds of books have been written on the relevance of Multiple Intelligences for educators and educational institutions (Chen, Moran \& Gardner, 2009). Additionally, Multiple Intelligences enhanced instruction may be implemented to support learning for individuals from preschool through college to foster the discovery of their own interests and talents (Rettig, 2005). Juteau (2006) introduced Multiple Intelligences infused instruction by having students complete an inventory designed to identify Multiple Intelligences strengths followed by class discussions prior to the implementation. Following the implementation of instruction, students reported that "they develop an awareness of themselves, and a realization that they are smart in their own way". According to Lumsden (1997), the use of Multiple Intelligences in classrooms supports the detection of intellectual strengths which results in increased efficacy and greater learning.

Using Multiple Intelligences in schools can guide the teachers for individualized education and also Multiple Intelligences inspired practices provide promising approaches for effective teaching and learning in schools (Birchfield, Thornburg, Megowan-Romanowicz, Hatton, Mechtley, Dolgov \& Burleson, 2008). In the light of Gardner's ideas, for effective teaching, 
the teachers' vital role is to observe the children individually and give instructions by taking into consideration of the children's background and their unique intelligences.

Teachers use several implications of Gardner's Theory of Multiple Intelligences in terms of classroom instruction. His theory states that all eight intelligences are needed to function productively in schools. Teachers, therefore, should think all intelligences are equally important. This is in contrast to the traditional education systems which typically place a strong emphasis on the development and use of verbal and mathematical intelligences. Thus, Multiple Intelligences implies that educators should recognize and teach children to a broader range of talents and skills (Silver, Strong \& Perini, 1997).

\section{Purpose and Significance of the Study}

The purpose of the current qualitative study was to evaluate the effectiveness of Multiple Intelligences on preschool children's learning styles, interests and active participation. Gardner (1983)'s theory states that individuals all possess multiple intelligences that combine and use in their own unique ways. According to Gardner (2006a), in every individual, each intelligence develops at its own rate, and teachers need to focus on establishing a profile of each learner. The current study is significant, because the results of this study may prove that the Multiple Intelligences theory is a good framework to prepare daily plans and build curriculum for children to be engaged and feel comfortable of their own learning. Additionally, previous research has been limited to the data collection procedures where some researchers used questionnaires (Delgoshaeia \& Delavaria, 2012, Almeida, Prieto, Ferreira, Bermejo, Ferrando $\&$ Ferrandiz, 2010), some used observations (Kuo, Su \& Maker, 2011), some used interviews (Padurean, 2011) but in this study, for a deeper investigation, several data collection procedures (a total of eight) were used such as applying daily plans inspired by Multiple Intelligences, scales, observations, video recordings of the implementations and interviews were used. 


\section{Method}

\section{Research Site and Participants}

This qualitative study was conducted with fourteen preschool children whose age was six (average of 58-month-old). The research group consisted of seven male children and seven female children and they were all from middle-class families. All of the participants were in the same full-day preschool program and in the same classroom located at a university campus in an urban area. It is located in the middle of the city and has an easy access. The university campus has plenty natural environments where children explore outdoors.

The classroom teacher who actively participated at the study as an implementer of the daily plan had an undergraduate degree in the field of Preschool Education and studying for her master's degree in the same field. She had been teaching in the current preschool for almost four years. Since this study was conducted in the second semester of the school year, she has been the teacher of this specific preschool classroom for more than seven months.

\section{Data Collection}

The data was collected from eight different sources which are numbered below in two phases:

In the first phase of the study, while the classroom teacher were conducting her usual semistructured daily plans based on the Ministry of National Education (MONE)'s National Preschool Education Curriculum, which is developmental and child-centered, she observed the children in her class to decide for their intelligences, learning styles, interests and participation throughout the days (1). After the teacher observed the class, for each child, she filled out the Multiple Intelligences Inventory (MULIN) developed by the researchers (2). During the child interviews, conducted by the one of the researchers (3), each child was asked to mark the Multiple Intelligences Self Evaluation Picture Control List (MISEC) developed by Fleetham (2008) (4). Before these interviews, one of the researchers showed the pictures of MISEC to the whole group one-by-one and explained what each picture meant. After this process, the interviews with the children took place in a private room in the preschool where the children are familiar with. There interviews were conducted individually and took 20 to 30 minutes for 
each child. The researcher, working with each child, first, asked about the child's interests and his/her favorite activities he/she liked to participate, and then she introduced the child the Multiple Intelligences Self Evaluation Picture Control List (MISEC) and asked the child which activities the child thought she/he did best. After each child marked the activities, he/she was allowed to talk about the activities he/she was attending.

In the second phase of the study, to evaluate the effectiveness of Multiple Intelligences on preschool children's learning styles, interests and active participation in the activities, the researchers prepared a Daily Plan Enriched with Multiple Intelligences Inspirations for this particular preschool class with the cooperation of the classroom teacher (5). While conducting the daily play in the class, the teacher observed the class focusing on the children's intelligences, learning styles, interests and participation (6). Professional observations of the two researchers and video recordings were done during the application of the daily plan enriched with Multiple Intelligences in the class (7). Finally, the teacher was interviewed by one of the researchers to find out whether there were differences on the children's intelligences, learning styles, interests and active participation during the daily plan enriched with multiple intelligences inspirations comparing with the semi-structured daily plan based on the Ministry of National Education's (MONE) National Preschool Education Curriculum conducted by the classroom teacher previously (8).

\section{a. Multiple Intelligences Inventory (MULIN)}

The researchers generated the items of the Multiple Intelligences Inventory (MULIN) based on the literature related with the theory of Multiple Intelligences. The inventory measures the eight dimensions of Gardner's Multiple Intelligences Theory (2006a), which are as follows: Linguistic Intelligence, Logical-Mathematical Intelligence, Musical Intelligence, Spatial Intelligence, Bodily-Kinesthetic Intelligence, Interpersonal Intelligence, Intrapersonal Intelligence and Environmental Intelligence. The scale originally consisted of 84 items where the teacher marks whether the child performs the behavior in that statement or not. Before the study, the classroom teacher and another teacher of the same preschool observed their own classes and filled out the inventory for two of the children of their classes, one performing high and one performing low, according to the teachers' observations for the last seven months. After getting the opinions of both teachers, and three experts working in the field of Early 
Childhood Education, the researchers rearranged the inventory by changing two items' wordings and deleting three incoherent items and one item which was not observed by both of the teachers. After all the validity and reliability studies, the final form of the inventory became 80 items in eight dimensions. Then, the classroom teacher filled out the inventory for each child of her class which is a total of 14 children.

\section{b. Multiple Intelligences Self Evaluation Picture Control List (MISEC)}

Multiple Intelligences Self Evaluation Picture Control List (MISEC), developed by Fleetham (2008) has 21 pictures. In every picture, there is a child or a group of children showing an activity related with one or two intelligence(s). During the communication with Fleetham, the researchers learned that he conducted the validity and reliability studies of the list and it has been used by numerous people for several years and the researchers got the permission to use the list. After showing the pictures one-by-one to the whole group and explained what each picture meant, one of the researchers worked individually with each child privately, first by asking about the child's interests and his/her favorite activities he/she liked to participate, then asked the child which activities the child thought she/he did best and by carefully looking at the pictures and discussed what kind of activity was done in each picture. Then, each child was asked to mark five things that she/he can do best. The researcher told each child that this may be different from the things they like to do. Children's each choice indicated one or two various intelligence strengths. After each child marked the activities, he/she was allowed to talk about the activities he/she was attending.

\section{Procedure}

In this qualitative study, to evaluate whether the theory of Multiple Intelligences affects the preschool children's learning styles, interests and active participation, first, the teacher prepared a semi-structured daily plan based on the Ministry of National Education (MONE)'s National Preschool Education Curriculum, which is developmental and child-centered, and the researchers prepared a daily plan with Multiple Intelligences inspirations where all the eight intelligences frequently functioned in the activities. This daily plan has also been prepared in order to meet different learning styles of the children in this particular preschool classroom and it was implemented in the class by the classroom teacher. By using observations, interviews 
with teachers, video recordings and scales [Multiple Intelligences Inventory (MULIN) and Multiple Intelligences Self Evaluation Picture Control List (MISEC)], the effects of the enriched daily plan on these preschool children's intelligences, learning styles, interests and active participation were evaluated.

The goals of the daily plan used in this study have been selected on the grounds of the past experiences of the children obtained by the observations of the classroom teacher where she has been the main teacher of them for the past seven months as well as the knowledge obtained from the Ministry of National Education (MONE)'s National Preschool Education Curriculum. After determining the goals of the daily plan, with the contribution of the class teacher, the researchers prepared seven activities where at least four intelligences and several learning styles were supported with each activity. The children were exposed to the Daily Plan Enriched with Multiple Intelligences Inspirations in the leadership of the classroom teacher. Two of the researchers observed and videotaped the class during the implementation of the whole plan.

At the beginning of the study, during the play time at the centers, the classroom teacher drew the attention of the children to the figures of the shapes (circle, ellipse, pentagon and hexagon) hanging on the wall, which were also the chosen concepts of the Daily Plan Enriched with Multiple Intelligences Inspirations. During the circle time, by the leadership of the teacher, the class talked about the different sizes and colors of these shapes and where these shapes can be found in daily life. After the circle time, for the first activity, which is the Language Arts Activity, the teacher read a story, interactively, where the children needed to solve a problem related with the story. Each child told and drew their own pictures related with their solutions for the problem. For the second activity, the children attended a Physical Activity, a competition, related with finding the right shapes including; circle, ellipse, pentagon or hexagon. Then, for the third activity, they took a short Field Trip, where the children were taken to the green areas of the university campus which the preschool was located. For the detailed examinations of the environment, they used magnifying glasses. They also took the interesting materials of nature with them to the classroom for detailed observations. The children were told that if they picked up living things from the nature, they needed to bring them back to the natural environment. After observing the natural materials in the classroom, for the fourth activity, which is the Science Activity, they watched videos of moving animals, 
talked about their movements and examined the photos of animals and their skeletons. Then, for the fifth activity, in pairs, they made animals with dough and skeletons of the animals with toothpicks and playdough at the Arts and Crafts Activity. For the sixth activity, which is the Drama Activity, they performed the impersonating of the skeletons of the animals with music in small groups. Finally, for the seventh activity of the day, which is the Pre-Literacy Activity, the children explored some pictures of the objects by working their short-term memories and talked about the relationships between the objects. The day was ended with another play time at the centers and an evaluation time where a big group discussion related with the activities took place. With interactive big and small group and individual work, all the eight intelligences were functioned productively several times throughout the Daily Plan Enriched with Multiple Intelligences Inspirations.

\section{Data Analysis}

Data collected from classroom observations, interviews, scales [Multiple Intelligences Inventory (MULIN) and Multiple Intelligences Self Evaluation Picture Control List (MISEC)], and video recordings during the implementations of the Daily Plan Enriched with Multiple Intelligence Inspirations were tallied, analyzed, and disaggregated in multiple steps. For the statistical analysis of the study, computer-based statistical software was used by the researchers. All the data gathered was, then, graphed to conclude the Multiple Intelligences Profile of this group of preschool children. Finally, based on the profile of the class, results of the data were examined to describe whether the Multiple Intelligences Inspired Daily Plan was effective on the attended 14 preschool children's intelligences, learning styles, interests and active participation in classroom instruction by comparing the observations with the regular every day activities.

\section{Findings}

The overarching purpose of this qualitative study was to evaluate the effectiveness of Multiple Intelligences on preschool children's learning styles, interests and active participation on activities. In order to evaluate the effectiveness of Multiple Intelligences in a group of preschool children, researchers conducted this study in an urban preschool class of 14 , with the 
cooperation of the classroom teacher. The data of the study was collected from several sources (recordings, observations, scales, interviews, implementation of a daily plan inspired by Multiple Intelligence) in two phases.

In this qualitative study, the findings from the data of interviews, observations, recordings and scales evaluated based on individual child. The findings of each child are as follows:

"E.S. was interested in each activity in the same degree and applied the directions given by the teacher carefully. She was sensitive for rhythm and dance. She was easily able to remember the objects in the activities requiring visual memory."

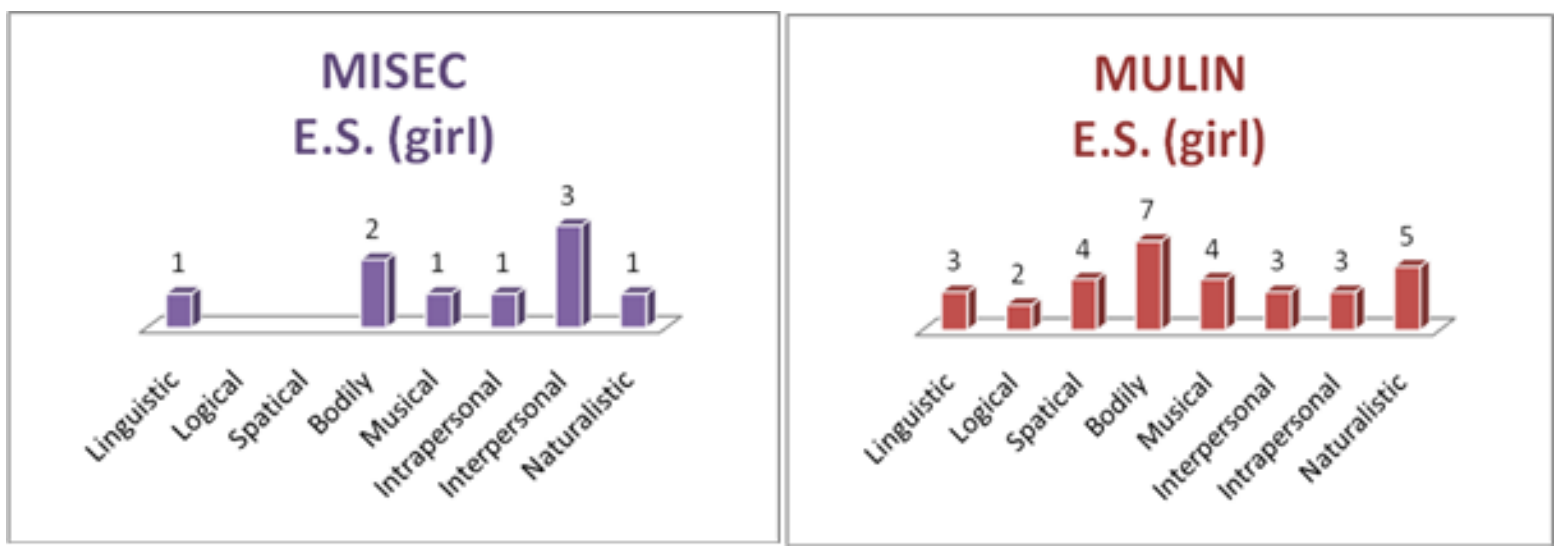

Figure 1. Data Gathered from the Scales for the Student E.S.

“亗.E.A. was impatient for the play activity. He had difficulty in waiting for his turn. He was really successful and willing in the movements requiring bodily coordination. He succeeded in producing different movements in drama activity. He made the animal imitations easily. He was very successful in conveying his thoughts. He prepared the animal models and their skeletons from play dough and toothpicks as if they were real. He also helped one of his friends after he finished his own work." 


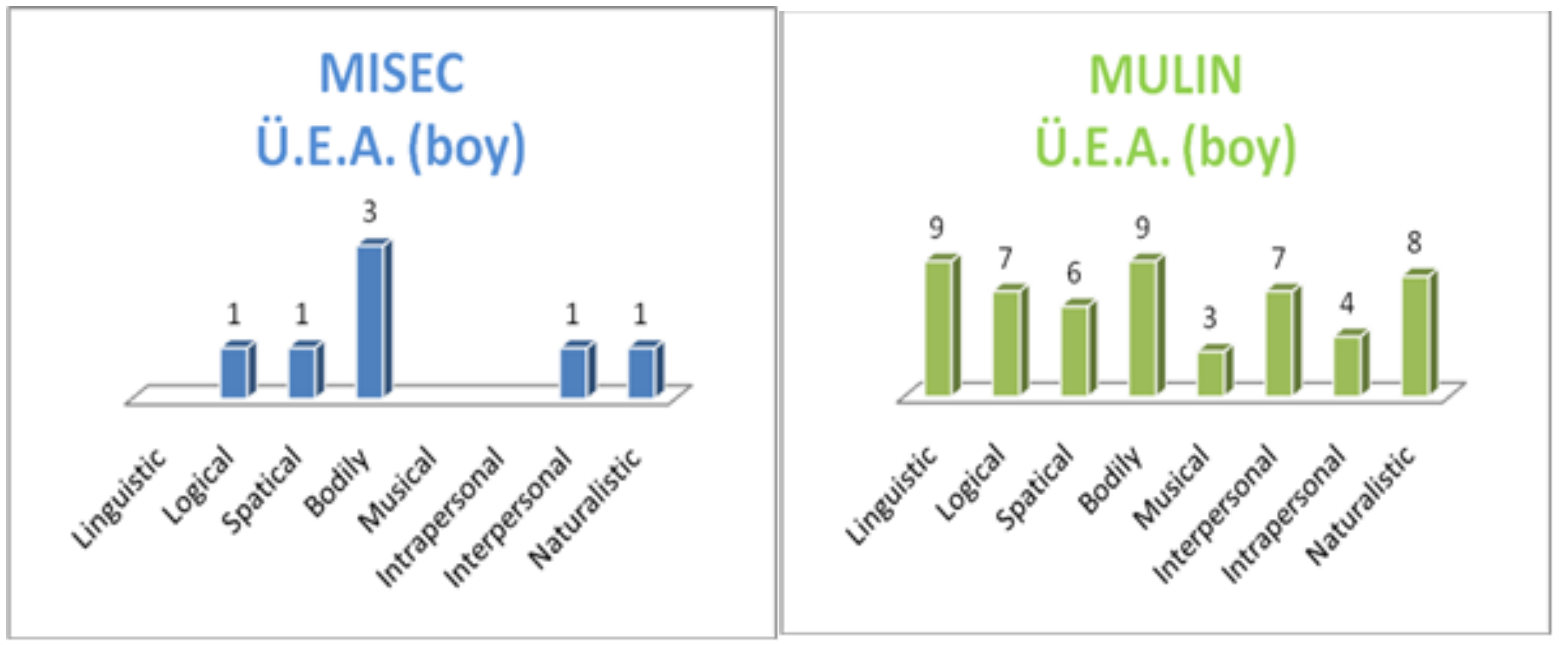

Figure 2. Data Gathered from the Scales for the Student Ü.E.A.

"C.K. was very careful and successful in the activities requiring visual memory and also in the activities requiring logic. She showed more interest in the activities requiring physical power and she carried out the related directions correctly. She had difficulty in sitting on her chair since she was very active. She was pretty well in producing dance moves suitable for the music. She expressed herself well in the activities requiring oral skills, too. She was quite successful in the pictures she drew in the art activity and the animals and its skeleton she made from play dough and toothpicks. She related the pictures which were cut with each other and used them in the ways suitable for her aim."

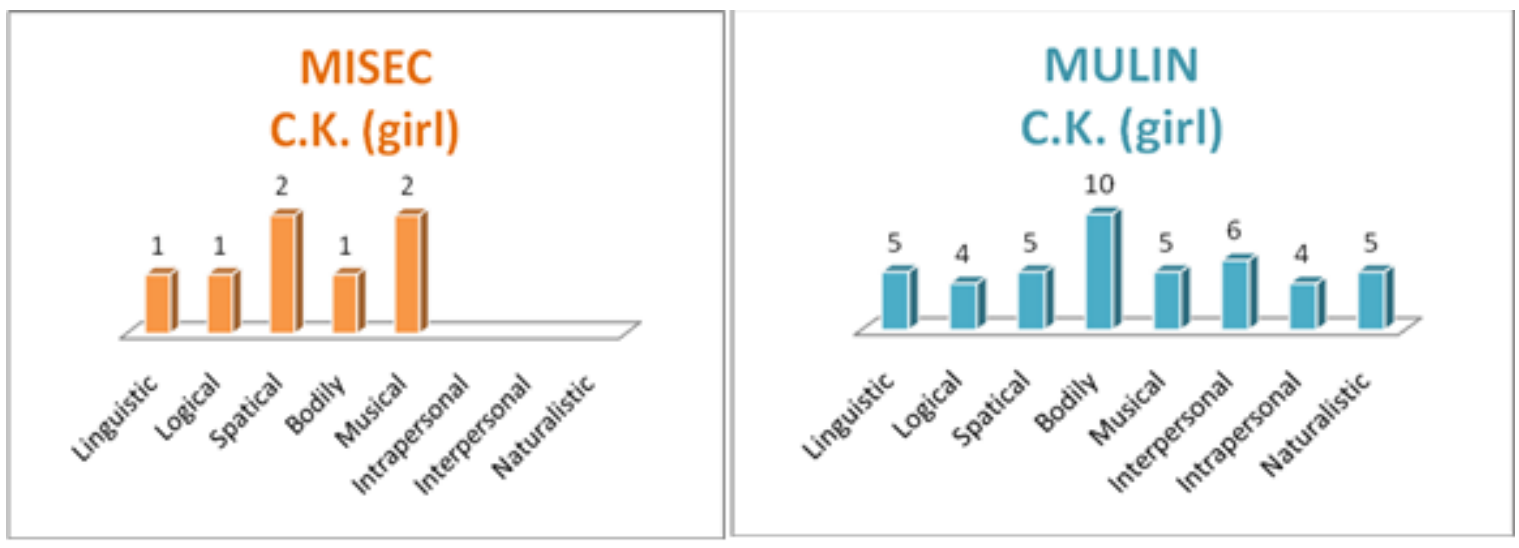

Figure 3. Data Gathered from the Scales for the Student C.K.

"C. $\ddot{U}$. observed his surrounding carefully in order to find different objects in the field trip. He was quite successful in imitations and dance. He was also good in the activities requiring hand skills." 


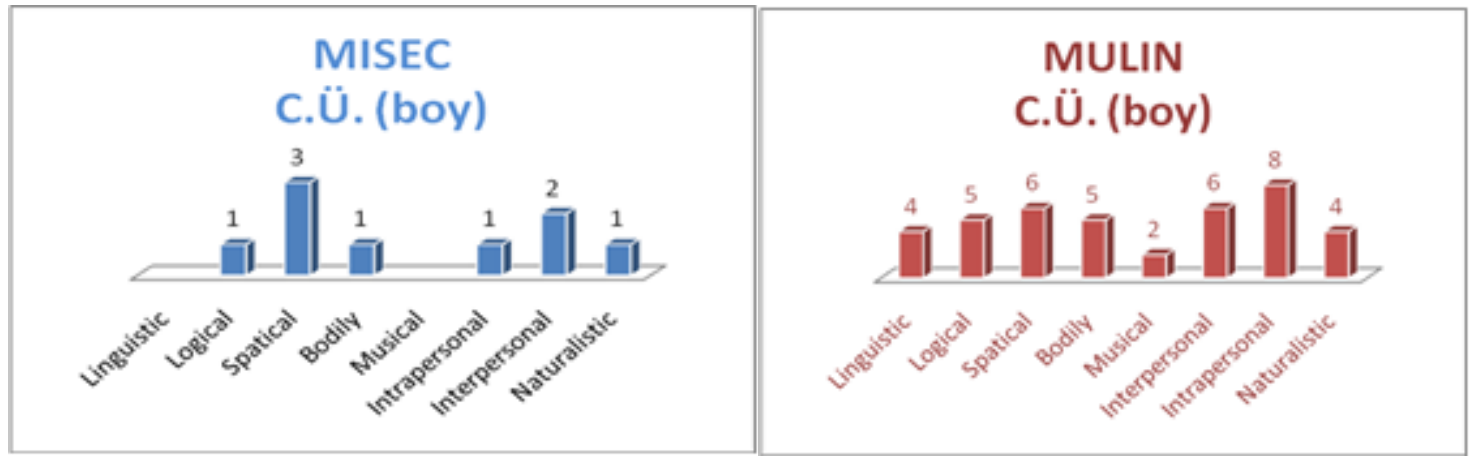

Figure 4. Data Gathered from the Scales for the Student C.Ü.

"Ş.N.B. didn't want to take part in the activities in which she thought she would exhibit a low performance. She continuously wanted help in the activities that she thought they were difficult and that she believed she couldn't succeed. She was good in sound and rhythm activities. At first, she thought that she wouldn't perform the activities requiring visual memory but she was easily able to make connections between the related objects in the pictures."

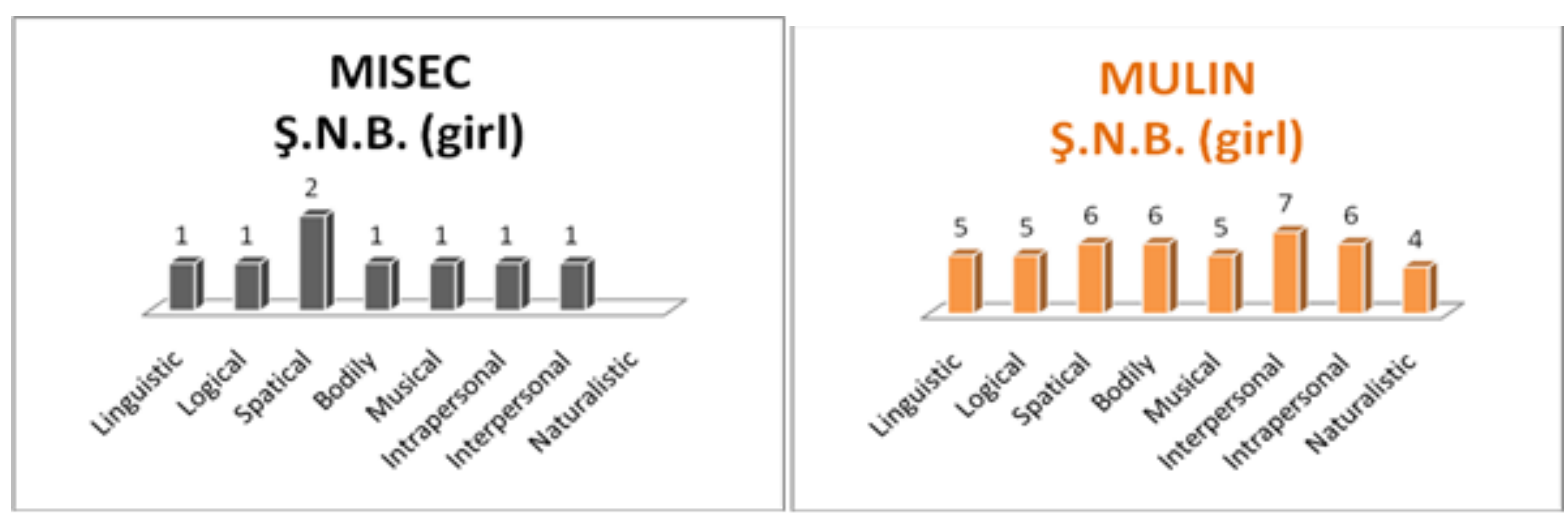

Figure 5. Data Gathered from the Scales for the Student Ş.N.B.

"E.K.S. was more interested in the activities requiring logic, visual and based on problem solving rather than the rhythmic activities. He watched the videos about animals carefully. He was easily able to convey his thoughts in the art activity. He worked harmoniously and successfully in the activities requiring small muscle skills." 


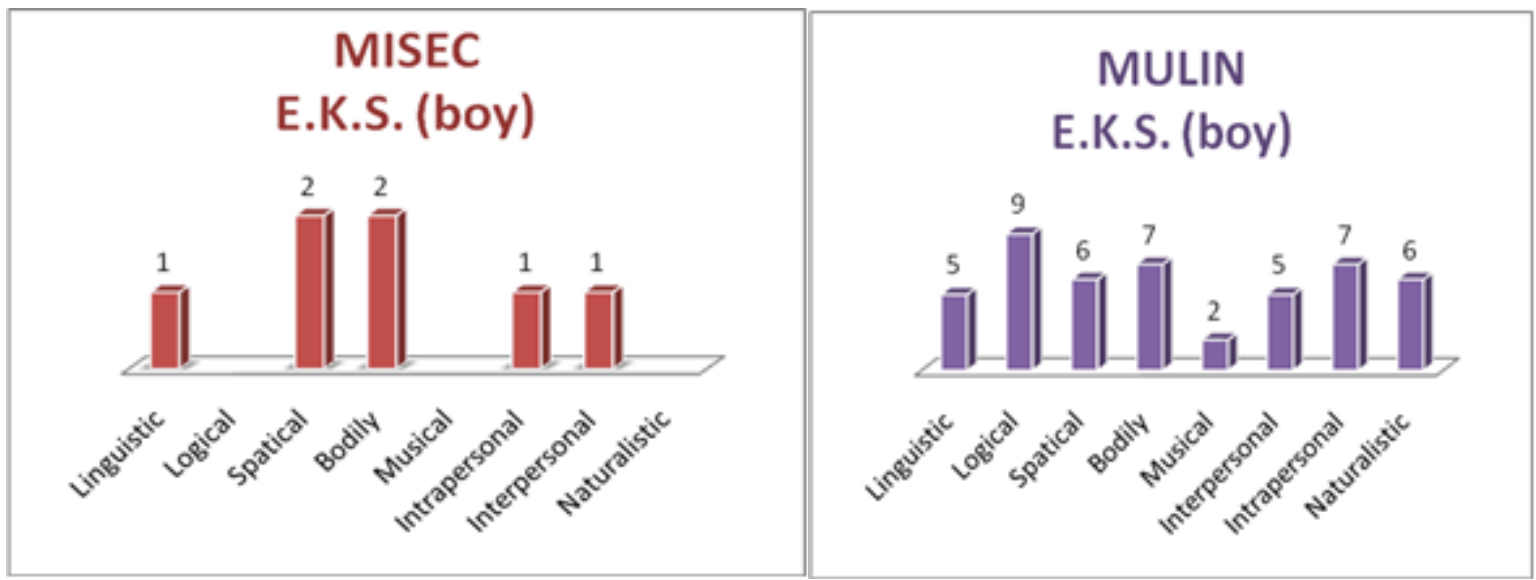

Figure 6. Data Gathered from the Scales for the Student E.K.S.

"I.K.A. was successful in sound and movement imitations. She was also quite good in the activities requiring hand skills and in using colors. The compositions she formed connecting the shapes cut great."
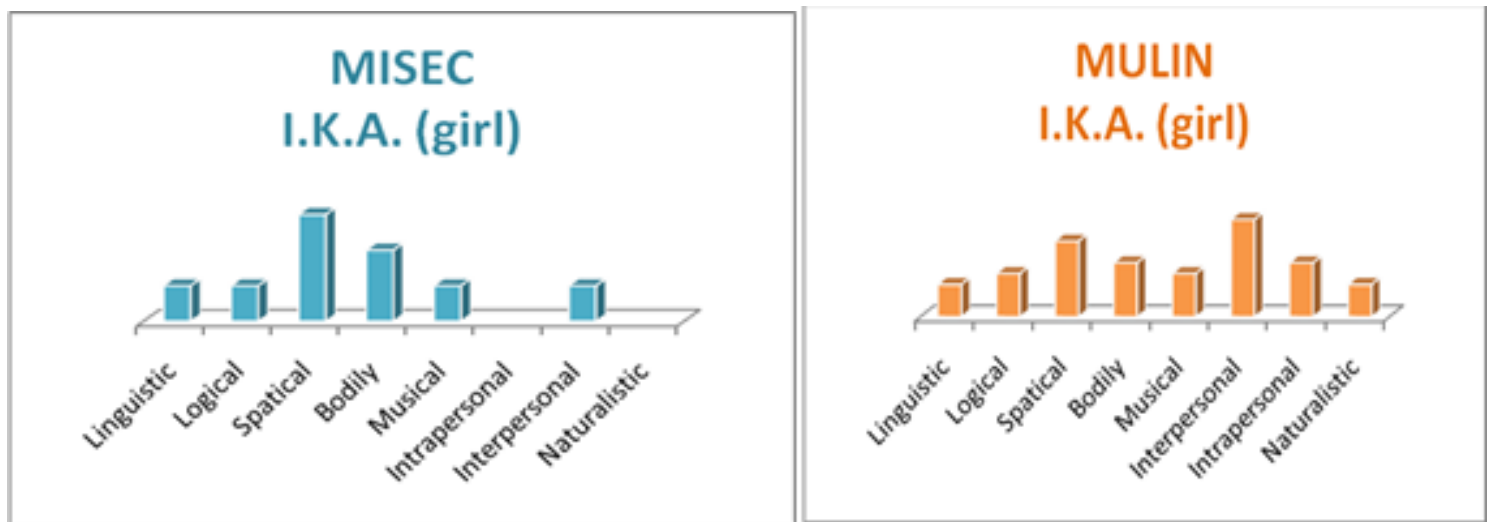

Figure 7. Data Gathered from the Scales for the Student I.K.A.

"E.SS. was successful in oral activities. Many objects in the field trip attracted him. He was sensitive for the events and the noises around him. He couldn't join the afternoon activities because she had to leave early."

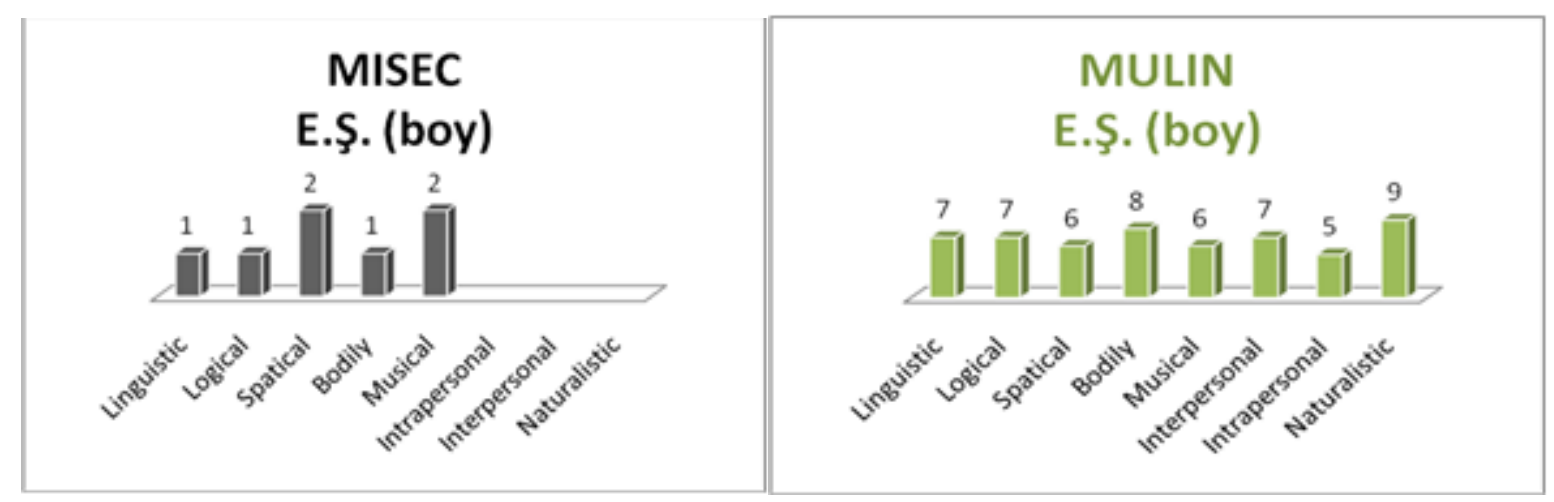

Figure 8. Data Gathered from the Scales for the Student E.Ş. 
"I.A. 's participation in the activities requiring physical power was quite high. She had difficulty in waiting for her turn in the activities and also in obeying the directions of the teacher. Her interest in the activities generally was little. She preferred saying the pictures which she had to keep in her mind by looking, not by remembering them."

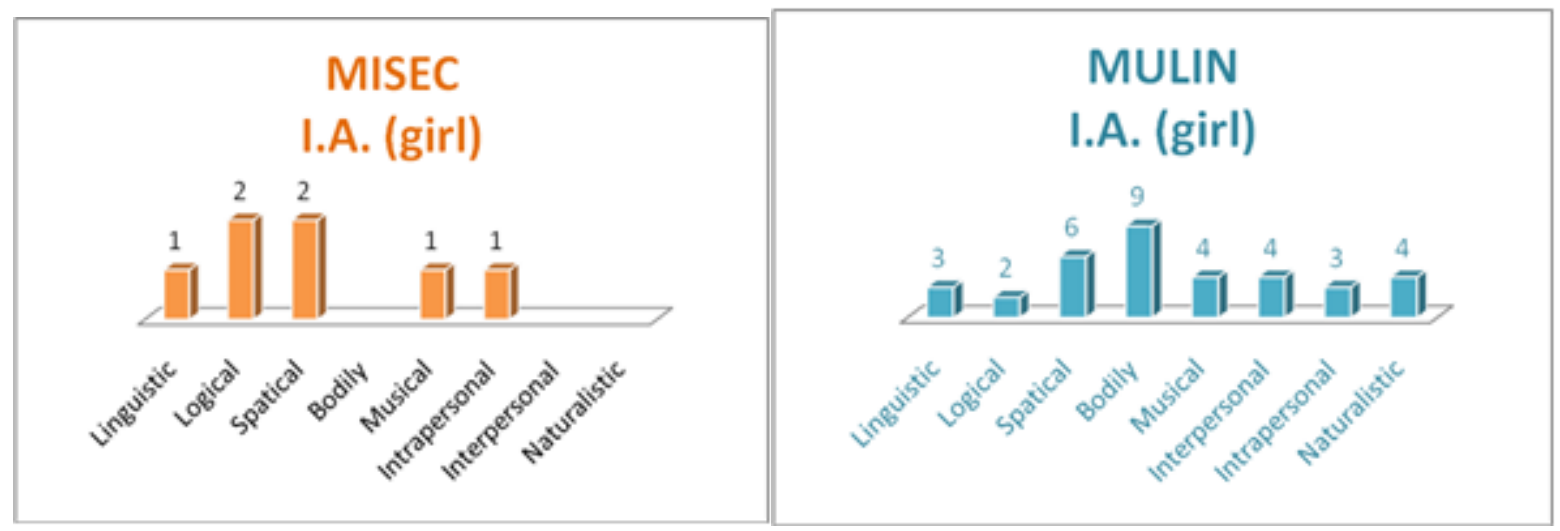

Figure 9. Data Gathered from the Scales for the Student I.A.

"A.B.D. was very willing in the play activity. The play took his attention and he performed the directions related with the play correctly. The videos that was watched related with the movements of the animals also took his attention very much. He was successful in the activities requiring hand skills. He was able to express his feelings that he wanted to tell in his drawings easily."

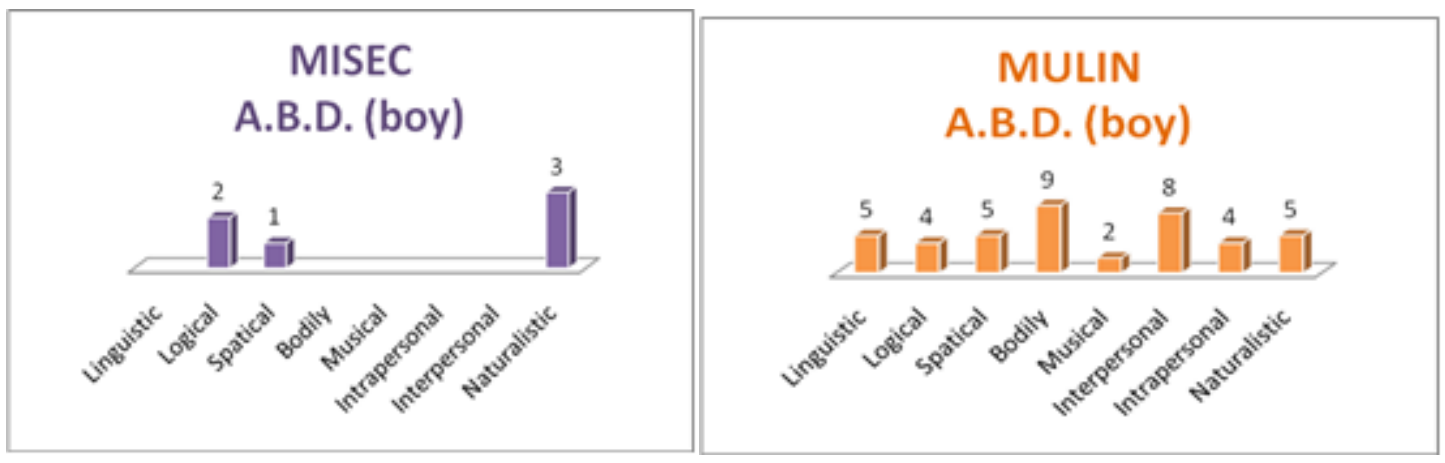

Figure 10. Data Gathered from the Scales for the Student A.B.D.

"For E.T., activities with sound and music were more attractive to her and her participation was higher. She wasn't interested in the field trip and animal videos very much. Since she wanted to be active, she had difficulty in sitting on her chair. She was able to use the pictures which were cut harmoniously. She was very good in the activities requiring small muscle skills. She succeeded in working with her friends cooperatively." 


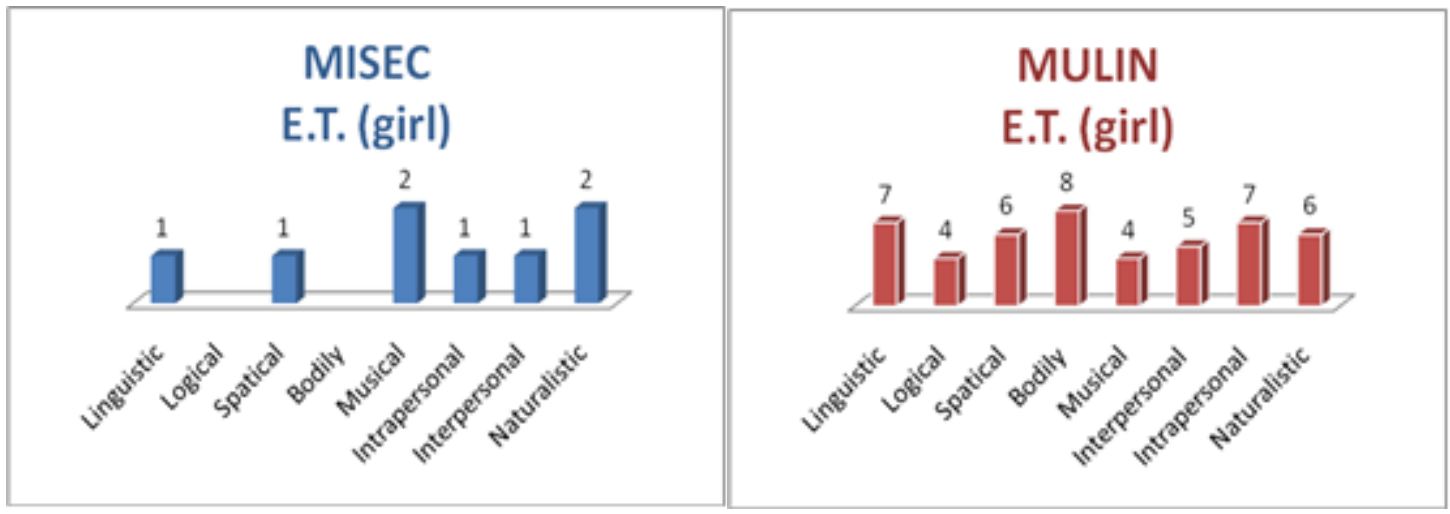

Figure 11. Data Gathered from the Scales for the Student E.T.

“O.K. $\ddot{U}$. got tired quickly in the activities. He really enjoyed animal imitations and performed them successfully. He showed a low performance in the activities which he normally would be able to achieve because he was ill."

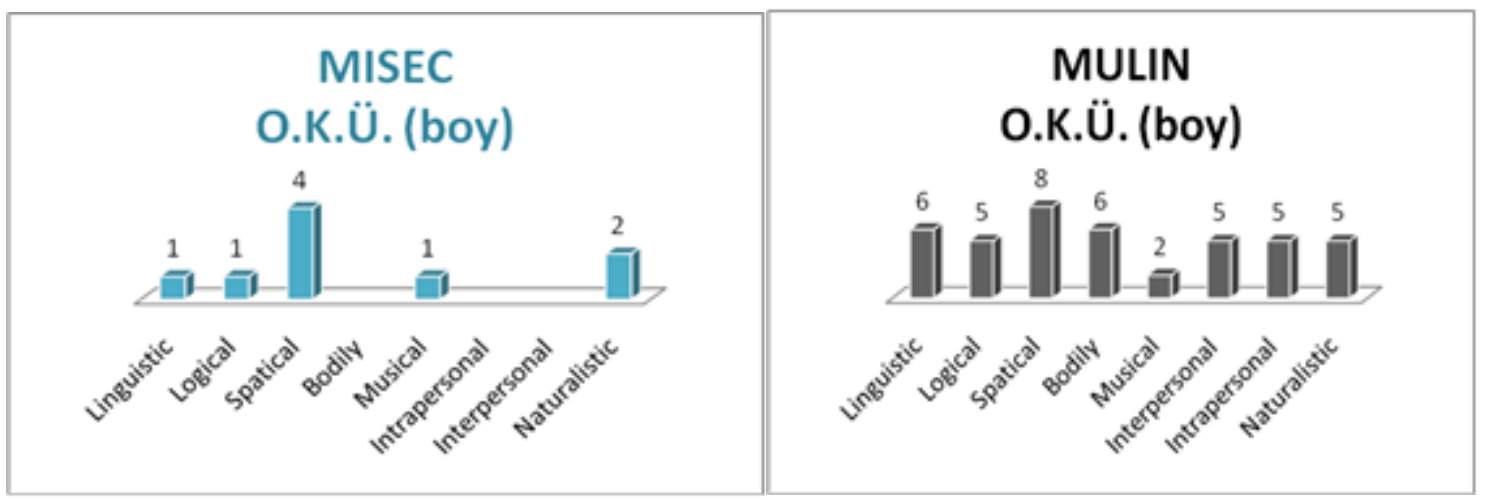

Figure 12. Data Gathered from the Scales for the Student O.K.Ü.

"M.Y. joined the activities in which there was rhythm. She was more sensitive in these types of activities and she caught the details and small differences very easily. She produced very beautiful products in the art activity with her ideas and harmonious colors she used in her pictures. She worked cooperatively with her friends in paired play."

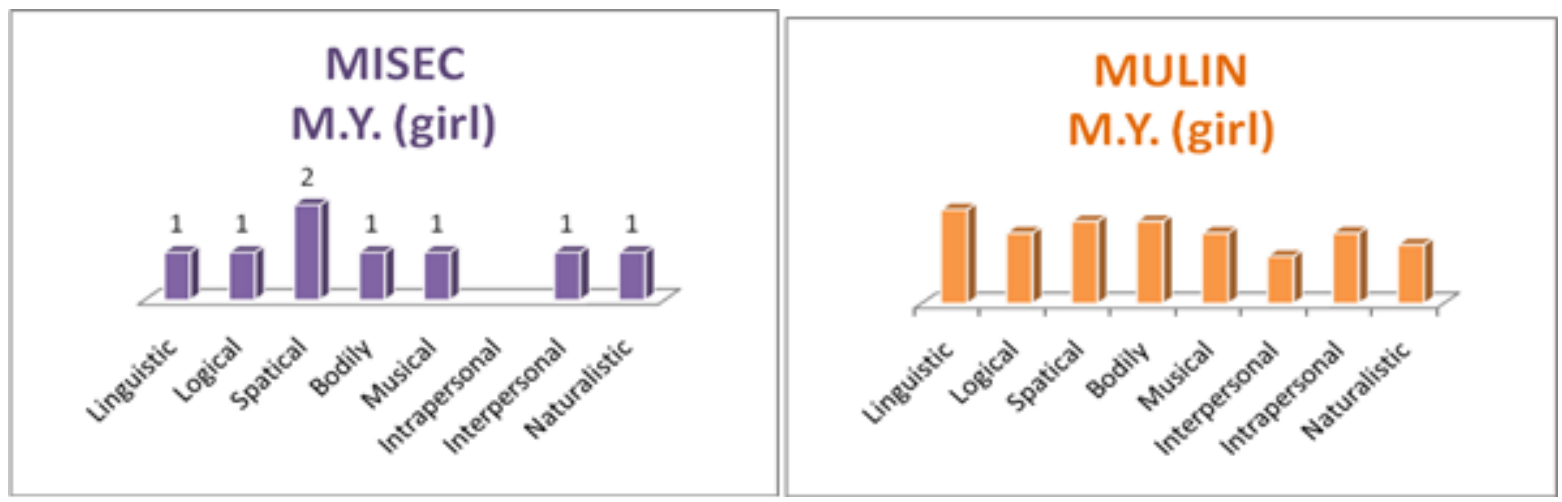

Figure 13. Data Gathered from the Scales for the Student M.Y. 
"T.M.A. was more successful in the activities requiring logic. Field trip and activities performed in nature didn't attract him. He took more pleasure in visual activities. He was willing and successful in the activities requiring body coordination."

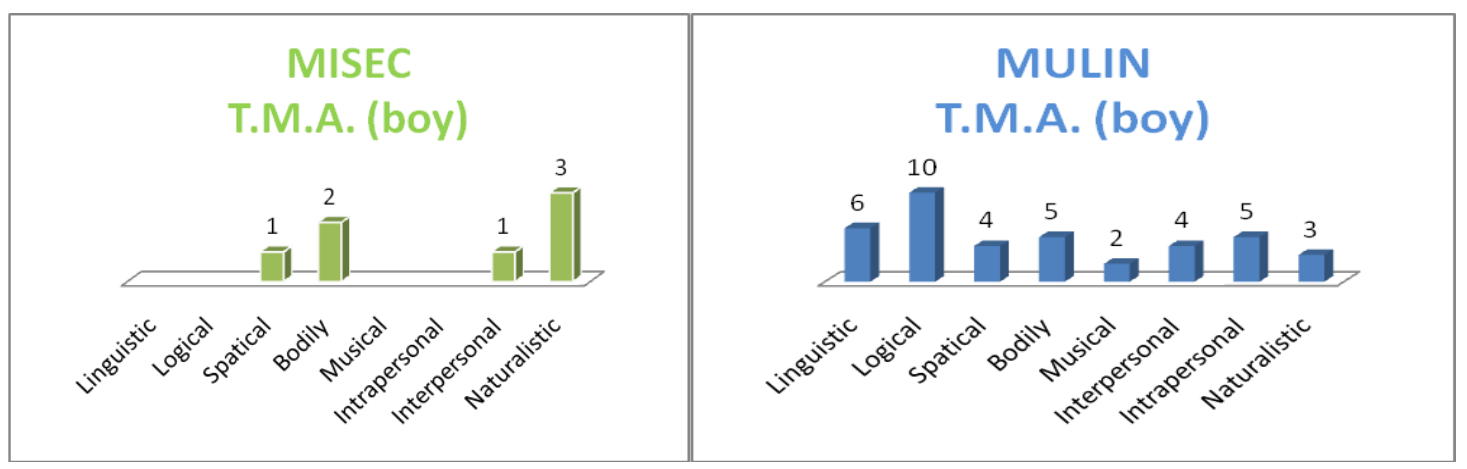

Figure 14. Data Gathered from the Scales for the Student T.M.A.

After evaluating each of the 14 children's several data, researchers, then, compared the Multiple Intelligences Self Evaluation Picture Control List (MISEC) scores and Multiple Intelligences Inventory (MULIN) scores of each child based on the dominant intelligences of the children. Findings of the comparisons of these two scales showed that the dominant intelligences of this group of preschool children were Spatial and Bodily Intelligences. Details of the comparisons can be found in Table 1 .

Table 1

Comparisons of MISEC and MULIN Scores of Each Child Based on Dominant Intelligences

\begin{tabular}{|c|c|c|}
\hline Children & $\begin{array}{l}\text { MISEC Scores Based of } \\
\text { Dominant Intelligences }\end{array}$ & $\begin{array}{l}\text { MULIN Scores Based of } \\
\text { Dominant Intelligences }\end{array}$ \\
\hline E.S (girl) & Interpersonal and Bodily Intelligence & Bodily and Naturalistic Intelligence \\
\hline Ü.E.A. (boy) & Bodily Intelligence & $\begin{array}{l}\text { Bodily, Linguistic and Naturalistic } \\
\text { Intelligence }\end{array}$ \\
\hline C.K. (girl) & Spatial and Musical Intelligence & Bodily and Interpersonal Intelligence \\
\hline C.Ü. (boy) & Spatial and Interpersonal Intelligence & Intrapersonal, Interpersonal and Spatial \\
\hline Ş.N.B (girl) & Spatial Intelligence & $\begin{array}{l}\text { Interpersonal, Intrapersonal, Bodily and } \\
\text { Spatial Intelligence }\end{array}$ \\
\hline E.K.S. (boy) & Spatial and Bodily Intelligence & $\begin{array}{l}\text { Logical, Bodily and Intrapersonal } \\
\text { Intelligence }\end{array}$ \\
\hline I.K.A. (girl) & Spatial and Bodily Intelligence & Spatial and Interpersonal Intelligence \\
\hline E.Ş. (boy) & Spatial and Musical Intelligence & Naturalistic and Bodily Intelligence \\
\hline I.A. (girl) & Logical and Spatial Intelligence & Bodily and Spatial Intelligence \\
\hline
\end{tabular}




\begin{tabular}{lll}
\hline Children & $\begin{array}{l}\text { MISEC Scores Based of } \\
\text { Dominant Intelligences }\end{array}$ & $\begin{array}{l}\text { MULIN Scores Based of } \\
\text { Dominant Intelligences }\end{array}$ \\
\hline $\begin{array}{l}\text { A.B.D. (boy) } \\
\text { E.T. (girl) }\end{array}$ & $\begin{array}{l}\text { Naturalistic and Logical Intelligence } \\
\text { Musical and Naturalistic Intelligence }\end{array}$ & $\begin{array}{l}\text { Bodily and Interpersonal Intelligence } \\
\text { Bodily, Linguistic and Intrapersonal } \\
\text { Intelligence }\end{array}$ \\
O.K.Ü. (boy) & Spatial and Naturalistic Intelligence & $\begin{array}{l}\text { Spatial, Bodily and Linguistic } \\
\text { Intelligence }\end{array}$ \\
M.Y. (girl) & Spatial Intelligence & $\begin{array}{l}\text { Linguistic, Spatial and Bodily } \\
\text { Intelligence }\end{array}$ \\
T.M.A. (boy) & Naturalistic and Bodily Intelligence & Logical and Linguistic Intelligence \\
\hline
\end{tabular}

\section{Results}

After reviewing the findings of the interviews, observations, the graphs of the scales [Multiple Intelligences Inventory (MULIN) and Multiple Intelligences Self Evaluation Picture Control List (MISEC)], and the comparisons of MULIN and MISEC scores of the children based on the children's dominant intelligences, the researchers generated the Multiple Intelligence Profile of this preschool class. The Multiple Intelligences Profile of the class showed that the children saw themselves as Spatially, Bodily and Naturalistically Intelligent whereas their classroom teacher saw the children as Bodily, Spatially and Interpersonally Intelligent. Based on the Multiple Intelligence Profile of the class, for both the children and the classroom teacher, Spatial and Bodily Intelligences were the common intelligences of the children. As it is mentioned in the theory of Multiple Intelligences (Gardner, 1983) that every person has all the intelligences in some degrees, other intelligences, mainly Linguistic, Logical, Intrapersonal and Musical Intelligences were also appeared in the scores of this group of children in different but lower percentages. By generating the Multiple Intelligence Profile of the class, the researchers had an approach about preparing the Daily Plan Enriched with Multiple Intelligences Inspirations.

Since the children's dominant intelligences were Spatial and Bodily Intelligences, the researchers prepared the daily plan where children can use all their intelligences but mainly their Spatial Intelligence; ability to draw accurate conclusions from observing a threedimensional (3D) environment, and their Bodily Intelligence; being good at body movement, performing actions and physical control. As it is mentioned in the work of Gardner (1999) that Spatial Intelligence involves interpreting and making judgments about the shape, size, 
movement, and relationships between surrounding objects, as well as the ability to envision and manipulate 3D models of things that are not immediately visible, the researchers prepared activities for children to use this form of reasoning. Additionally, researchers included activities involving Bodily Intelligence where children are strong and tend to have excellent hand-eye coordination and dexterity.

According to the findings of the scales, interviews, video recordings and observations, it was determined that Daily Plan Enriched with Multiple Intelligences Inspirations made a positive effect on the attended 14 preschool children's interests and active participation on their dominant intelligences and learning styles. In the last phase of the study, during the interview with the classroom teacher, she specifically mentioned that while she was routinely applying semi-structured daily plans based on the Ministry of National Education (MONE)'s National Preschool Education Curriculum, some of the children were not actively participating and they got bored easily even at the very beginning of the activities, but for this study, during the Daily Plan Enriched with Multiple Intelligences Inspirations, since the activities were organized based on the children's dominant intelligences and learning styles, children were more active and involved in the activities. Classroom teacher explained her thoughts about how the children and herself acted during this enriched daily plan in these words:

"First, the class was arranged to apply the enriched daily plan and all the necessary materials were made ready in the class. Different levels of affectivity of the activities made the application easier. Each child found the opportunity to express himself/herself and it helped me not to have any difficulties in taking their attention. At least four or five kinds of intelligences were used in each activity in this plan, prepared by taking Multiple Intelligence Theory at the base, helped me take pleasure from it. The children and I both enjoyed ourselves during the activities. However, because it was an intensive plan which we all are not used to, it became necessary to shorten some activities."

During the interview, the classroom teacher also had some comments on the enriched daily plan itself. Her words related with the assessment of the daily plan are as follows:

"The activities in the enriched plan were very attractive and interesting for the children in my class. Because it was heavily raining in the field trip, we turned back to the class earlier and we couldn't observe the insects and animals on campus in a sufficient amount of time. For this reason, I told the children that we are going to watch the insects and animals online. The daily plan was applied without any 
incidents except the rain. But we deeply processed and compared the collected material in class. It was not a planned activity but some of the children who have musical intelligence wanted to produce different sounds by using the collected materials. They even danced with the materials while making these sounds. The materials prepared were interesting for the children. The first stage of the drama activity took a very long time and the children were observed to be tired, I asked the children to cut the activity but the children resisted to continue so the other two stages were performed shortly. They were highly interested."

Results of this qualitative study not only provide insight into the role of the theory of Multiple Intelligences on children's interests and active participation to the activities but also draw attention to the importance of having all the eight multiple intelligences and different kinds of learning styles in the daily plans of preschools since children show more interest on the activities they had dominant intelligence.

\section{Discussion and Implications}

Before considering the implications of the current study and the possibility of similar research, it is important to consider the possible limitation of the study. This limitation lies with the amount of observation time. Although researchers carefully considered the amount of time and compared it to similar previous research, it is difficult to determine whether a full day of classroom observations were sufficient to see the instruction in action in preschool classrooms. Although the focus of the current study was observing the children on a daily instruction in a preschool, it is certainly possible that the research may be provided during a few days- or a few weeks- instruction. This could provide the researchers for an understanding of the effects of Multiple Intelligences Inspired Curriculum in a preschool. Additionally, covering all the eight intelligences in the daily plan made the plan very intense. By preparing a whole-yearcurriculum inspired by Multiple Intelligences would spread the activities in days and solve the problem of intensiveness.

The current study proved that Multiple Intelligences can be applied in the daily activities of preschool classrooms and preparing activities where children can use their dominant intelligences would improve their intelligences and make them actively participated in the daily activities. Research also supports the results of this study. For example; according to Norel, Niculescu, Usaci \& Lupu (2009)'s study, using Multiple Intelligences in classes encourages 
the active participation of the children in the educational activities and make them learn in a fun and engaging way since the activities are based on their interests. Actively participating children also lead the teachers to become more effective in the classroom settings. In Lai Imm \& Bahauddin (2008)'s study, it is mentioned that meaningful learning experience emphasizes active participation of children in activities so the child can apply learning with daily life experience, overall it results with effective learning and this can be happened with implementing the theory of Multiple Intelligences in classrooms.

Studies exploring Multiple Intelligence in preschool classrooms show that children develop in several areas. For example, in Gündüz ve Özcan (2017)'s research, after conducting a curriculum related with Multiple Intelligence for a school year, 5-year-old children's ( $N=24)$ linguistic/verbal intelligence, spatial intelligence, bodily kinesthetic and naturalist intelligence were highly developed and positive effects were seen in their logical-mathematical intelligence, musical intelligence, interpersonal intelligence and intrapersonal intelligence. Parallel to those results, according to the study of Delgoshaei \& Delavari (2012), applying Multiple Intelligence approach in the preschool classrooms of 40 children as an educational method caused increase in all domains of the participating children's development. In a study of Economidou Stavrou, Chrysostomou, \& Socratous (2011), the pre-primary school children who participated in their study responded with enthusiasm to innovative activities based on Multiple Intelligences and benefit in several ways. In addition, since each child was given the opportunity to better understand the concepts taught, they led their own ways of learning.

Schools worldwide have often sought to help children develop a sense of accomplishment and self-confidence. Gardner's theory of Multiple Intelligences provides a theoretical foundation for recognizing the different abilities and talents of children. Although National Preschool Education Curriculum of Ministry of National Education (MONE) was prepared based on the theory of Multiple Intelligences besides other theories of early childhood education, it is not common for teachers to prepare daily plans for declamation of all the eight intelligences and all the learning styles of the children. This theory acknowledges that while all children may not be verbally or mathematically gifted, children may have dominance in other areas, such as bodily and spatial relations as it is the current situation of this study. Similar to the current research, in Özdemir Beceren (2010)'s study, children's spatial relations were also found to dominant. According to her study, 232 4-to-6-year old children were selected from different 
socio-economic backgrounds and both boys' and girls' spatial intelligence were leading. In some areas of the country where children has less contact with nature, this may not be the situation. For this reason, carrying some activities outdoors may help covering the children's need of spatial and movement needs. Similarly, in Erkan \& Öztürk (2013)'s study on 208 kindergarteners from different socioeconomic backgrounds, for musical intelligence, children from middle socioeconomic status scored higher than the children from low socioeconomic status. This result can be interpreted as teachers working in the low socioeconomic areas may have other priorities than music activities. The results of these studies lead educators to the idea that teachers need to use more music and visual reinforcements and take children outdoors where they may feel more comfortable since they may use their different intelligences and they may learn better.

Based on research in literature, Multiple Intelligences also allows the children to learn the content of the curriculum better. For example, based on Kelly (2006)'s study, developing understanding and/or insight on the learning activities allows active participation or passive reflection of the children. Additionally, a child-centered pedagogy, like Multiple Intelligences promotes active participation in the activities, physical engagement with the materials used, self-directed learning through sensory experience and spontaneous creativity derived from experiences (Huang, 2013).

Throughout the world, based on the concept knowledge of newer curriculum of the preschools, early childhood educators already realized that the curriculum content should be selected from the aspects of children's background experience, respect each child's unique development, raise of comprehensive early childhood development, admire the learning style of each child and fulfill the needs and interests of children, especially all types of intelligences (Jiang, 2011). According to the results of the current study, approaching and assessing learning in this manner allows a wider range of children to participate actively and successfully in the preschool classroom learning. In the light of the results of this study, while implementing the everyday activities, it is a necessity for teachers to meet all the eight intelligences of the preschool children in their classrooms.

Authors' Note: We would like to thank the preschool staff, especially Demet Özer, the classroom teacher, for participating to this study. 


\section{References}

Aronoff, F. W. (1988). Reaching the young child through music: Howard Gardner's Theory of Multiple Intelligences as model. International Journal of Music Education, 12(1), 18-22.

Bednar, J. (2002). Improving student motivation and achievement in mathematics through teaching to the Multiple Intelligences. Master's Thesis. Chicago: Saint Xavier University.

Birchfield, D., Thornburg, H., Megowan-Romanowicz, C., Hatton, S., Mechtley, B., Dolgov, I., \& Burleson, W. (2008). Embodiment, multimodality, and composition: Convergent themes across HCI and education for mixed-reality learning environments. Journal of Advances in Human-Computer Interaction, 2008, 1-19.

Bordelon, D. E., \& Banbury, M. M. (2005). Pursuing the parameters: Validating the Multiple Intelligences Inventory for teachers. Assessment for Affective Intervention, 30, 33-51.

Carlisle, A. (2001). Using Multiple Intelligences Theory to assess early childhood curricula. Young Children, 56(6), 77-83.

Checkley, K. (1997). Teaching for Multiple Intelligences: A conversation with Howard Gardner. Educational Leadership, 55(1), 12.

Chen, J., Moran, S., \& Gardner, H. (2009). Multiple intelligences around the world. New York: Jossey-Bass.

Delgoshaei, Y., \& Delavari, N. (2012). Applying multiple-intelligence approach to education and analyzing its impact on cognitive development of pre-school children. ProcediaSocial and Behavioral Sciences, 32, 361-366.

Economidou Stavrou, N., Chrysostomou, S., \& Socratous, H. (2011). Music Learning in the Early Years: Interdisciplinary Approaches Based on Multiple Intelligences. Journal for Learning through the Arts, 7(1), 1-14.

Erkan, S., \& Öztürk, B. (2013). A study on the multiple intelligences of kindergarteners from different socioeconomic backgrounds. Procedia - Social and Behavioral Sciences, 106, 250-258.

Fleetham, M. (2009). Multiple Intelligent Applications. Retrieved April 25, 2018, from http://www.thinkingclassroom.com/Parents/MI_Applications_Resources.aspx

Furnham, A., \& Thomas, C. (2004). Parents' gender and personality and estimates of their own and their children's intelligence. Personality and Individual Differences, 37, 887-903. 
Gardner, H. (1983). Frames of mind: The theory of Multiple Intelligences. New York: Basic Books.

Gardner, H. (1993). Frames of mind: The theory of Multiple Intelligences. (10 anniversary ed.). New York, NY: Basic Books.

Gardner, H. (1999). The disciplined mind: What all students should understand. New York: Simon \& Schuster.

Gardner, H. (2006a). Multiple intelligences: New horizons. New York: Basic Books.

Gardner, H. (2006b). Replies to my critics. In J. A. Schaler (Ed.). Howard Gardner under fire: The rebel psychologist faces his critics. (pp. 277-344). Chicago: Open Court.

Gardner, H., \& Hatch, T. (1989). Multiple Intelligences go to school: Educational implications of the Theory of Multiple Intelligences. Educational Researcher, 18(8), 4-9.

Guss, F.G. (2005). Dramatic playing beyond the Theory of Multiple Intelligences. Research in Drama Education, 10(1). 43-54.

Gündüz, N., \& Özcan, D. (2017). The Development of Multiple Intelligence with Storytelling. International Journal of Educational Sciences, 15(1-2), 242-251.

Highland, S. (1999). Improving student behavior through the use of Multiple Intelligences. Master's Thesis. Chicago: Saint Xavier University.

Jiang, F. (2011). Selection of Kindergarten Curriculum Content under the New Curriculum Ideas. Journal of Changsha Normal College, (4), 9-21.

Kuo, C.C., Su, F.L., \& Maker, C. J. (2011). Cultivating Problem Solving Abilities in Gifted Preschoolers. Gifted Education International, 27(3), 311-326.

Lai Imm, J.L., \& Bahauddin, A. (2008) The Effects of Colours on Preschoolers' Behaviour: An analysis of Colour-Mood Association on Preschoolers Aged 4 to 6. In: 2nd International Conference on Built Environment in Developing Countries, $3^{\text {rd }}-4^{\text {th }}$ December 2008, Universiti Sains Malaysia, Pulau Pinang.

Ministry of National Education. (MONE) (2006). Preschool Education Curriculum (For 36 through 72 Months Old Children). Ankara: MEB Publications.

Norel, M., Niculescu, R. M., Usaci, D., \& Lupu, D. (2009). Valuing the Theory of Multiple Intelligences in Formal Curriculum. New Trends. In Proceedings of the 11th WSEAS International Conference On Mathematical Methods And Computational Techniques In Electrical Engineering (pp. 441-445). World Scientific and Engineering Academy and Society (WSEAS). 
Özdemir Beceren, B. (2010). Determining multiple intelligences pre-school children (4-6 age) in learning process. Procedia - Social and Behavioral Sciences, 2(2), 2473-2480.

Padurean, A. (2011). Interactive Teaching Methods for Pre-School and Primary School Pupils. Journal Plus Education/Educatia Plus, 7(2), 156-163.

Rettig, M. (2005). Using the Multiple Intelligences to enhance instruction for young children and young children with disabilities. Early Childhood Education Journal, 32(4), 255260.

Silver, H., Strong, R., \& Perini, M. (1997). Integrating learning styles and Multiple Intelligences. Educational Leadership, 55(1), 22-27. 